\title{
Critical Analysis of Audit Committee Reporting in National Government Departments: The Case of South Africa
}

\author{
Tankiso Moloi \\ Financial Governance, College of Accounting Sciences, University of South Africa \\ emolois1@unisa.ac.za
}

\section{ABSTRACT}

The paper critically assesses audit committee reporting in South Africa's national government departments (NGDs). During the review, it was established that, from the regulatory perspective, there were limited guidelines relating to the extent and nature of information that should be reported on the audit committee reports, whereas the main contribution of the paper are uniform benchmark features of audit committee reporting in the South Africa's national government departments. These benchmark features (categories) were developed using an inductive or bottom up thematic analysis which was applied on the applicable regulations as well as on all NGD's annual reports to determine the comprehensive themes and patterns of audit committee reporting across the departments. It is recommended that those audit committees in NGDs that do not currently report on these themes should expand their reporting to be comprehensive by including these themes.

Using the established benchmark features in the form of themes, audit committees reports were coded and analysed to determine the disclosure of information relating to these themes. It was found that majority of categories reported on audit committee reports and analysed lacked transparency as to the role of audit committees in providing oversight in the NGDs concerned. In addition to the recommended audit committee themes, the paper further recommends that audit committees in NGDs should also consider voluntary disclosing of some additional information on their oversight activities. Disclosure of additional voluntary information would improve the usefulness of audit committee reports as users of this information would gain and understanding of yearly audit committee activities as of the nature of oversight and strategic engagements audit committees would have had with the management as well. The potential benefit for users of audit committee reports in NGDs is envisaged as flexibility, exposure and access to different dimensions of information reported by different NGDs. The potential benefit for audit committee members is grounded on the users' perception of audit committee reports, in this instance, the improvement in perception on their independence.

Keywords: audit committees, reporting, national government departments, South Africa, thematic analysis

JEL:M4

Moloi, T. (2015). Critical Analysis of Audit Committee Reporting in National 


\section{Introduction}

Historically, audit committees were formed voluntary in both private and public sector to play a role in the organisation's control environment, however, this governance structure has evolved overtime to become an integral part of governance (Marx, 2009), and its modern role now includes being a financial watchdog for interested stakeholders in an organisation (Klein, 2002; Agoglia et al., 2011). Beasley et al. (2009) concur with the description of the modern role of audit committees and they note that audit committees are increasingly responsible for an overall oversight of assurance processes in large organisations. It is on this basis that Bhasin (2012) proposes that the modern era audit committee could be a powerful tool that could promote reliability and transparency of financial information of an organisation.

The South African public sector has had a regulation in place that regulates the establishment audit committees for almost 5 past years now. These regulations are Public Finance Management Act of 1999 (RSA, 1999) and the Treasury Regulations (National Treasury, 2001). In a nutshell, these regulations require that each public sector institution establishes an audit committee whose main role and responsibilities are to coordinate and provide oversight on all assurance activities of the institution so as to eliminate or minimise the opportunity for fraudulent activities (or other undesirable activities) resulting from lack of controls. It is noted that the role and responsibilities of audit committees as required by the regulations of South Africa do not appear to contradict the role suggested and highlighted in the introductory defined as the modern role and responsibilities of audit committees.

Even if the regulation and the established structures are meant to minimise undesirable activities through oversight and assurance, the South African public sector has recorded instances of non-adherence to proper financial management. This challenge appears to be increasing as evident from the Consolidated general report on the national and provincial audit outcomes 2012-13 where the Auditor-General of South Africa (2013) noted that there were continuing high levels of unauthorised, irregular as well as fruitless and wasteful expenditure in South Africa's public service.

It has been stated that the South African regulations order that audit committees should be established in public service institutions as "financial watchdogs" to contribute in the improvement of control environment of the institutions in which they are appointed so that cases such as those mentioned in the Auditor-General of South Africa's report are eliminated/reduced. With the increasing challenges raised by the Auditor-General of South Africa, the essential question is how audit committees perform their oversight role in the national government departments to combat undesirable effects. Put it differently, what activities are audit committees engaged in to improve the control environment in the national government departments in which they operate and how this is communicated to the stakeholders. 
As such, the main aim of this study is to critically analyse the audit committee reporting in South Africa's national government departments with a view of determining sufficiency of the contents of audit reports and whether the information contained in these audit committee reports is meaningful in a sense that it provides an understanding of what the audit committee activities were during the year as well as the nature of oversight and engagements the audit committee would have had with the management to improve the control environment.

There was no benchmark as to the information features that need to be reported on the NGDs audit committee reports. In this manner, an inductive or bottom up thematic analysis had to be conducted so as to determine the themes and patterns of reporting (See the details on the application of this methodology in Section 4). Therefore, the secondary purpose became the establishment of benchmark features of audit committee report in South Africa's NGDs.

The immediate limitation of this study was that it evaluated audit committee reports of national government departments. Provincial government departments, institutions established in terms of Chapter 9 of the South African Constitution, municipalities and state-owned companies were not evaluated and thus, they present an opportunity for further research in this area. In addition to the limitations noted above, four (4) NGDs annual reports could not be located on their websites and any other potential source and some national government departments had been consolidated following the general elections in May 2014. Therefore, the findings contained in this paper relate to the thirty four (34) NGDs that were analysed.

The remainder of this paper is structured in the following manner: an overview of audit committee requirements in the public sector followed by a review of existing literature on audit committee reporting. Afterwards, a section describing the methodology applied followed by a section presenting the research results, and finally, an analysis and interpretation of the findings are provided. In the final part, the recommendations are drawn from the study and the conclusions are presented.

\section{Overview of Audit Committees Requirements in South Africa's Public Sector}

In the South African public sector, audit committees are regulated through Section 76 as well as Section 77 of the Public Finance Management Act (RSA, 1999) read in conjunction with the Treasury's Regulation 3.1 (National Treasury, 2001). These regulations mandate the accounting officer of the department (in consultation with the relevant authority) to set up an independent audit committee which should operate in terms of written terms of reference. 
In terms of Section 76 as well as Section 77 of the Public Finance Management Act (RSA, 1999) read in conjunction with the Treasury's Regulation 3.1 (National Treasury, 2001), the following should be adhered to with regards to the audit committees:

- The chairperson of an audit committee must be independent, knowledgeable of the status of the position, have the requisite business, financial and leadership skills, and may not be a political office bearer.

- Audit committees must be constituted so as to ensure their independence and their membership must be disclosed in the annual report of the institution.

- Members of an audit committee who have been appointed from outside the public service pursuant to the Section 77(a)(i) of the Public Finance Management Act should have appropriate experiences.

- Relevant executive authority should concur with any premature termination of the services of a person serving on an audit committee.

- Audit committee should operate in terms of written terms of reference which should deal adequately with its membership, authority and responsibilities. The terms of reference should be reviewed at least annually to ensure its relevance.

It should be disclosed in the institution's annual report whether or not the audit committee has adopted formal terms of reference and, if so, whether the committee satisfied its yearly responsibilities in compliance with the terms of reference (RSA, 1999; National Treasury, 2001). With regards to the reviews and a high-level oversight that need to be undertaken by the audit committee of the NGD concerned with a view to improve the control environment in an institution in which the audit committee operates, the audit committee must review the following as enacted by the legislative requirement:

- Effectiveness of internal control systems;

- Effectiveness of internal audit function;

- Risk areas of the institution's operations to be covered in the scope of internal and external audits;

- Adequacy, reliability and accuracy of the financial information provided to the management and other users of such information;

- Any accounting and auditing concerns identified as a result of internal and external audits;

- Institution's compliance with legal and regulatory provisions; and

- Activities of internal audit function, including its annual work programme, coordination with the external auditors, reports of significant investigations and responses of management to specific recommendations (National Treasury, 2001). 
The legislative framework provides the audit committee with powers to investigate matters within its mandate as identified in the written terms of reference. To this extent, the PFMA and the Treasury Regulations (RSA, 1999 and National Treasury, 2001) call for the audit committees to be granted resources it requires to investigate any matter within their terms of reference by granting full access to information.

With the exception of Section 3.1.9 which deals with the adoption and compliance of the terms of reference that should be reported in the audit committee report, and Section 3.1.13 which requires that the annual report should be carried by the audit committee introducing the comments on effectiveness of internal control, on quality of in-year management and monthly/quarterly reports submitted in terms of the Public Finance Management Act and the Division of Revenue Act as well as the comments on the audit committee's evaluation of annual financial statements (National Treasury, 2001), it was noted that not much was said about the extent and nature of information that should be contained in the audit committee reports. With the lack of guidelines relating to the extent and nature of information that should be reported on the audit committee reports, it would be difficult to determine how audit committees performed their oversight role in the national government departments to combat undesirable effects as the mechanism which determines what should be reported on is not present. It would be further difficult to determine the nature of activities that audit committees were engaged in to improve the control environment in the national government departments in which they operate so as to communicate and build confidence with the stakeholders that something was being done to improve the control environment.

\section{Overview of the Existing Literature on Audit Committee Reporting}

There was not much work done on the subject of audit committee reporting in South Africa, both in private sector and public sector. However, the work has been done on a broader topic of audit committees and such work includes the works performed by van der Nest (2006 and 2008) and van der Nest, Thornhil and de Jager (2008) in the South African public sector as well as Marx (2009) on top 40 listed companies featured in the Johannesburg Securities Exchange (JSE).

In the South African public sector, van der Nest (2005) undertook a study that evaluated the performance of audit committees with regards to risk management, financial reporting oversight, internal control and corporate governance from the heads of internal auditing perspectives. Since the focus was not on audit committee reporting, there were no findings made in this regard. In another study aimed at investigating the perceived effectiveness of audit committees in the South African public service, van der Nest (2008) 
found that audit committees could still improve their performance of certain key functions, such as oversight on risk management, governance, financial reporting, internal control and support of external audit function. Once more, the focus of the study was not on audit committee reporting and, as such, there were no findings on this area.

In a study entitled Audit committees and Accountability in the South African Public Sector, van der Nest, Thornhil and de Jager (2008) viewed audit committees as key contributors to proper governance in the public sector and their study found that in some national government departments audit committees were not effective. Again, since the aim of the study was not focused on audit committee reporting, there were no findings in this regard.

In the South African private sector, Marx (2009) investigated the responsibilities performed and the disclosure practices of audit committees in large listed companies in South Africa. Marx's (2009) findings were that audit committees properly performed their traditional responsibilities of overseeing external audit, internal audit, financial reporting, internal control and risk management. Further, Marx (2009) found that audit committees dealt with emerging issues, such as integrated report and ethics compliance reasonably satisfactorily. However, regarding the audit committee reporting, Marx (2009) found that the observed companies performed poorly.

In the United States, Carcello, Hermanson and Neal (2002) took a random sample of 150 proxy statements in the spring of 2001 to study the disclosures in audit committee charters and reports. Their study aimed at understanding the audit committee activities and also at the identification of possible areas for further audit committee reform. Their findings have revealed that there was a high level of compliance with the mandated audit committee disclosures, such as disclosures related to reviewing and discussing the financial statements with the management. Their study however observed that a voluntary disclosure of audit committee activities was more common for depository institutions, larger companies, NYSE listed companies, and companies with more independent audit committees (Carcello et al., 2002).

In another study conducted in the United States, Rezaee, Olibe and Minmier (2003) conducted a content analysis exercise to determine the level and extent of audit committee disclosures in the Fortune 100 companies. Their study found that there was a high level of audit committee disclosures amongst the observed Fortune 100 companies.

On an international scale, particularly in private sector, focus on audit committee reporting is increasing. A group known as Audit Committee Collaboration (2012) consisting of the organisations, such as the National Association of Corporate Directors, the Corporate Board Member/NYSE Euronext, Tapestry Networks, the Directors' Council, the Association of Audit Committee Members, Inc., and the Center for Audit Quality have all been at 
the forefront with regards to the calls for improvement in the audit committee reports. The Audit Committee Collaboration (2012) has called for institutions to enhance audit committee reporting by arguing that this is an important element that is surely to promote the investors / stakeholders' education on the audit committee's critical responsibilities as well as the audit committees' effectiveness of executing its responsibilities. Accordingly, audit committee reports are to be enhanced by changing formats of reporting, streamlining and consolidating all audit committee related information where possible into a meaningful report.

One of the recent studies of audit committee reports was recently undertaken by the Financial Reporting Lab (2013) in the United Kingdom. The Financial Reporting Lab report found that investors / stakeholders did not read much of the audit committee reports because, in their view, amongst other things:

- Audit committee reports did not have sufficient content;

- Sometimes there was repetition of information that has been already disclosed somewhere else in the annual report;

- Audit committee reports contained much in the "letter" but not much in the spirit; and

- Audit committee reports contained rhetoric and clutter, whereas investors wanted more meaningful information (Financial Reporting Lab, 2013).

\section{Research Method Followed}

This paper critically analysed information reported on audit committee reports to gain insight into the nature of audit committee activities and its strategic engagements with the NGD's management. To achieve this objective, audit committee reports for all NGDs had to be analysed to identify the themes and reporting patterns within the audit committee reports. As such, a methodology that was deemed suitable for this purpose is known as thematic analysis.

Daly et al. (1997) support the use of thematic analysis in studies that search for themes emerging as important to the description of a certain phenomenon. Another description of thematic analysis that is consistent with the above is provided by Braun and Clarke (2006) where thematic analysis is described as a method that can be used in identifying, analysing and reporting patterns (themes) within the data.

Antaki et al. (2002) criticise thematic analysis as a methodology that lacks clear and concise guidelines which result in "anything goes" approach. Other researchers such as Attride-Stirling (2001), Boyatzis (1998) as well as Tuckett (2005) have all raised concern that there is no clear agreement about what thematic analysis is and how a researcher should go about applying it in a study. To address this weakness, Braun and Clarke (2006) proposed 
step-by-step guidelines for conducting thematic analysis, emphasising the importance of thematic analysis as a flexible and useful research tool which has a potential of providing detailed analysis of complex data.

Table 1: Established themes emanating from inductive thematic analysis

\begin{tabular}{|c|c|}
\hline First order themes established & Second order themes established \\
\hline $\begin{array}{l}\text { FO Theme } 1 \text { - Committee } \\
\text { members and their meeting } \\
\text { attendance }\end{array}$ & $\begin{array}{l}\text { SO Theme } 1.1 \text { - Disclosure of identity and qualification of audit } \\
\text { members } \\
\text { so Theme } 1.2 \text { - Disclosure of number of meetings by each member }\end{array}$ \\
\hline $\begin{array}{l}\text { FO Theme } 2 \text { - Audit committee } \\
\text { responsibilities }\end{array}$ & $\begin{array}{l}\text { SO Theme } 2.1 \text { - Indication of whether there was compliance with } \\
\text { responsibilities arising from section } 38 \text { (1) (a) of the Public } \\
\text { Finance Management Act (PFMA) } \\
\text { so Theme } 2.2 \text { - Indication of whether there was compliance with } \\
\text { Treasury Regulation } 3.1 \\
\text { so Theme } 2.3 \text { - Responsibility of adopting the formal terms of } \\
\text { reference as a charter } \\
\text { so Theme } 2.4 \text { - Responsibility of conducting the audit committee } \\
\text { affairs in compliance with the charter }\end{array}$ \\
\hline $\begin{array}{l}\text { FO Theme } 3 \text { - Effectiveness of } \\
\text { internal control system }\end{array}$ & $\begin{array}{l}\text { SO Theme } 3.1 \text { - Realisation and indication that internal controls } \\
\text { are a cost effective assurance for safeguarding of assets and } \\
\text { effectively liabilities and working capital } \\
\text { SO Theme } 3.2 \text { - Reviewing the state of internal controls within the } \\
\text { NGD concerned indicating whether there were instances of non- } \\
\text { compliance and repeat findings } \\
\text { SO Theme } 3.3 \text { - Reporting on strategic role of audit committee in } \\
\text { monitoring corrective actions }\end{array}$ \\
\hline $\begin{array}{l}\text { FO Theme } 4 \text { - Quality of } \\
\text { reporting }\end{array}$ & $\begin{array}{l}\text { SO Theme } 4.1 \text { - Reviewed content and quality of monthly and } \\
\text { quarterly reports in the year under review } \\
\text { so Theme } 4.2 \text { - Reviewing of reports relating to the information } \\
\text { submitted by management on the pre-determined objectives } \\
\text { (performance information) }\end{array}$ \\
\hline $\begin{array}{l}\text { FO Theme } 5 \text { - Evaluation of } \\
\text { annual financial statements } \\
\text { and compliance }\end{array}$ & $\begin{array}{l}\text { SO Theme } 5.1 \text { - Responsibility to review financial statements } \\
\text { SO Theme } 5.2 \text { - Responsibility of reviewing AGSA's report and } \\
\text { management response to such a report } \\
\text { SO Theme } 5.3 \text { - Responsibility of evaluating and reviewing changes } \\
\text { to accounting policies and practices } \\
\text { SO Theme } 5.4 \text { - Responsibility of evaluating and reviewing } \\
\text { compliance with legal and regulatory provisions } \\
\text { SO Theme } 5.5 \text { - Evaluation and reviewing of the pre-determined } \\
\text { objective information to be part of the annual report } \\
\text { SO Theme } 5.6 \text { - Evaluation and reviewing significant adjustments as a } \\
\text { result of audits (should there be any) }\end{array}$ \\
\hline FO Theme 6 - Internal audit & $\begin{array}{l}\text { SO Theme } 6.1 \text { - Reporting on the effectiveness of internal audit } \\
\text { function in addressing risks pertinent to the NGD concerned } \\
\text { so Theme } 6.2 \text { - Monitoring implementation of audit plans approved } \\
\text { by the audit committee }\end{array}$ \\
\hline FO Theme 7- Risk management & $\begin{array}{l}\text { SO Theme } 7.1 \text { - Risk management reviews including reviewing of risk } \\
\text { management strategy } \\
\text { so Theme } 7.2 \text { - Monitoring of risk management activities including } \\
\text { the implementation plan in the NGD concerned }\end{array}$ \\
\hline $\begin{array}{l}\text { FO Theme } 8 \text { - Engagements } \\
\text { with Auditor-General of SA }\end{array}$ & $\begin{array}{l}\text { SO Theme } 8.1 \text { - Engagement with Auditor General of SA so as to } \\
\text { ensure that there are no unresolved matters }\end{array}$ \\
\hline
\end{tabular}

For the purpose of this paper, there was no benchmark as to what NGDs audit committee reports should contain. In this manner, an inductive or bottom up thematic analysis had to be conducted. Braun and Clarke (2006) view an inductive thematic analysis as "a process of coding the data without trying to fit it into a pre-existing coding frame, or the researcher's analytic pre-conceptions". An inductive thematic analysis followed a process where 
a benchmark was established by analysing the legislative and regulatory requirements contained in the PFMA (RSA, 1999) and the Treasury Regulations (National Treasury, 2001) in conjunction with all audit committee reports to identify the themes and reporting patterns. Table 1 contains the identified themes and NGDs audit committee reporting patterns.

For the purpose of analysing how NGDs performed in reporting the benchmark information, the coding principles were formulated and used in coding and analysing relevant information from the NGDs audit committee reports. Once the determination was made in line with the formulated coding principles, the information was then entered into the code-book for analysing performance. Formulated coding principles for the themes reported in the audit committee reports were based on the guidelines that if the audit committee report contains the coded category of information, the item is marked as YES in the designed code-book. On the contrary, if the audit committee report analysed does not contain the coded category of information, the item will be marked $\mathrm{NO}$ in the designed code-book.

With regards to the data, it was established that in all reports, the information on audit committee reports was contained in the governance section of the NGDs annual report. As such, obtaining the annual reports for all NGDs was an important component of this study. The list with links of all NGDs was then obtained from the National Treasury and it was used to access the NGDs websites in order to download the annual reports.

During the collection phase, it was noted that two NGDs were consolidated as part of the Presidency's annual report (they did not have separate annual reports for analysis). Annual reports for the other four (4) departments could not be located on their websites or any other potential source. The rest of the NGDs (34) had their annual reports published on their websites. In addition to publishing their annual reports on their respective websites, thirty two (32) NGDs annual reports were available on the government online website.

For a detailed analysis and presentation, the South African national government departments were categorised based on the economic cluster. The classification of NGDs was based on the list obtained from the National Treasury of South Africa. This is a list kept by the National Treasury for the purpose of overseeing the Chief Financial Officers' forum (CFOs). 
Table 2: Classification of national government departments

\begin{tabular}{|c|c|c|}
\hline \multirow{6}{*}{ 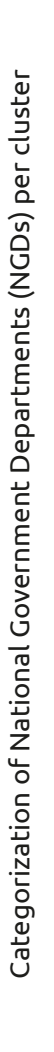 } & Central & Finance \\
\hline & $\begin{array}{l}\text { a) Cooperative Governance and } \\
\text { Traditional Affairs } \\
\text { b) Home Affairs } \\
\text { c) International Relations } \\
\text { d) Monitoring and Evaluation (in } \\
\text { the presidency) } \\
\text { e) Presidency } \\
\text { f) Public Works } \\
\text { g) Women, Children and People } \\
\text { with Disabilities (in the } \\
\text { presidency) }\end{array}$ & $\begin{array}{l}\text { a) Department of Public } \\
\text { Enterprises } \\
\text { b) Department of Public Service } \\
\text { Administration } \\
\text { c) Department of } \\
\text { Telecommunications } \\
\text { d) Public Service Commission } \\
\text { e) National Treasury } \\
\text { f) National School of Government } \\
\text { g) Statistics South Africa }\end{array}$ \\
\hline & \multicolumn{2}{|c|}{ Economic } \\
\hline & $\begin{array}{l}\text { a) Agriculture } \\
\text { b) Communications } \\
\text { c) Economic Development } \\
\text { d) Energy } \\
\text { e) Environmental Affairs } \\
\text { f) Human Settlement } \\
\text { g) Mineral Resources }\end{array}$ & $\begin{array}{l}\text { h) Rural Development and Land } \\
\text { Reform } \\
\text { i) Science and Technology } \\
\text { j) Tourism } \\
\text { k) Trade and Industry } \\
\text { l) Transport } \\
\text { m) Water Affairs }\end{array}$ \\
\hline & Justice & Social \\
\hline & $\begin{array}{l}\text { a) Correctional Services } \\
\text { b) Defence } \\
\text { c) Independent Police } \\
\text { Investigative Directorate } \\
\text { d) Justice and Constitutional } \\
\text { Development } \\
\text { e) Military Veterans } \\
\text { f) South African Police Service } \\
\text { g) National Prosecuting Authority }\end{array}$ & $\begin{array}{l}\text { a) Arts and Culture } \\
\text { b) Basic Education } \\
\text { c) Health } \\
\text { d) Higher Education } \\
\text { e) Labour } \\
\text { f) Social Development } \\
\text { g) Sports and Recreation }\end{array}$ \\
\hline
\end{tabular}

Source: Author's own illustration of information sourced from the National Treasury

There are five (5) clusters used by the National Treasury for the purpose of categorizing NGDs namely: central cluster, finance cluster, economic cluster, justice cluster as well as the social cluster. The economic cluster contains thirteen (13) NGDs and this is almost twice as the rest of other clusters while the rest of the clusters contain seven (7) NGDs.

\section{Research Findings and Interpretation}

The research findings presented below demonstrate the results of content analyses performed on the audit committee reports for national government departments (NGDs). 
Table 3: Consolidated analyses of audit reports for NGDs

\begin{tabular}{|c|c|c|c|}
\hline Category observed & $\begin{array}{l}\text { Total } \\
\text { NGDs } \\
\text { assessed }\end{array}$ & Yes & No \\
\hline $\begin{array}{l}\text { Committee members and attendance: identity and qualification of } \\
\text { members }\end{array}$ & 34 & 29 & 5 \\
\hline $\begin{array}{l}\text { Committee members and attendance: number of meetings by each } \\
\text { member }\end{array}$ & 34 & 33 & 1 \\
\hline $\begin{array}{l}\text { Audit committee's responsibilities: compliance with responsibilities } \\
\text { arising from section } 38 \text { (1) (a) of the Public Finance Management } \\
\text { Act (PFMA) }\end{array}$ & 34 & 30 & 4 \\
\hline $\begin{array}{l}\text { Audit committee responsibilities: compliance with Treasury } \\
\text { Regulation } 3.1\end{array}$ & 34 & 32 & 2 \\
\hline $\begin{array}{l}\text { Audit committee responsibilities: adoption of the formal terms of } \\
\text { reference as a charter }\end{array}$ & 34 & 32 & 2 \\
\hline $\begin{array}{l}\text { Audit committee responsibilities: conducting the affairs in } \\
\text { compliance with the charter }\end{array}$ & 34 & 33 & 1 \\
\hline $\begin{array}{l}\text { Effectiveness of internal controls: cost effective assurance for } \\
\text { safeguarding of assets and effectively liabilities and working capital }\end{array}$ & 34 & 9 & 25 \\
\hline $\begin{array}{l}\text { Effectiveness of internal controls: the state of internal control } \\
\text { within the NGD concerned i.e. indicating whether there were } \\
\text { instances of non-compliance and repeat findings }\end{array}$ & 34 & 31 & 3 \\
\hline $\begin{array}{l}\text { Effectiveness of internal controls: the role of audit committee in } \\
\text { monitoring corrective actions }\end{array}$ & 34 & 24 & 10 \\
\hline $\begin{array}{l}\text { Quality of reporting: reviewing of reports relating to the } \\
\text { information submitted by management on the pre-determined } \\
\text { objectives (performance information) }\end{array}$ & 34 & 10 & 24 \\
\hline $\begin{array}{l}\text { Quality of reporting: content and quality of monthly and quarterly } \\
\text { reports in the year under review }\end{array}$ & 34 & 20 & 14 \\
\hline $\begin{array}{l}\text { Evaluation of annual financial statements: reviewing of financial } \\
\text { statements }\end{array}$ & 34 & 34 & 0 \\
\hline $\begin{array}{l}\text { Evaluation of annual financial statements: reviewing AGSA's report } \\
\text { and management response to such a report }\end{array}$ & 34 & 26 & 8 \\
\hline $\begin{array}{l}\text { Evaluation of annual financial statements: reviewing changes to } \\
\text { accounting policies and practices }\end{array}$ & 34 & 21 & 13 \\
\hline $\begin{array}{l}\text { Evaluation of annual financial statements: reviewing compliance } \\
\text { with legal and regulatory provisions }\end{array}$ & 34 & 20 & 14 \\
\hline $\begin{array}{l}\text { Evaluation of financial statements: reviewing the pre-determined } \\
\text { objective information to be part of the annual report }\end{array}$ & 34 & 16 & 18 \\
\hline $\begin{array}{l}\text { Evaluation of annual financial statements: reviewing significant } \\
\text { adjustments as a result of audits (should there be any) }\end{array}$ & 34 & 22 & 12 \\
\hline $\begin{array}{l}\text { Internal audit and risk review: effectiveness of internal audit } \\
\text { function in addressing risks pertinent to the NGD concerned }\end{array}$ & 34 & 28 & 6 \\
\hline $\begin{array}{l}\text { Internal audit plans: monitoring implementation of audit plans } \\
\text { approved by the audit committee }\end{array}$ & 34 & 29 & 5 \\
\hline Risk management reviews: reviewing of risk management strategy & 34 & 20 & 14 \\
\hline $\begin{array}{l}\text { Risk management activities: monitoring of risk management } \\
\text { activities including the implementation plan in the NGD }\end{array}$ & 34 & 21 & 13 \\
\hline $\begin{array}{l}\text { Engagement with Auditor General of SA meeting with AGSA to } \\
\text { ensure that there are no unresolved matters }\end{array}$ & 34 & 34 & 0 \\
\hline
\end{tabular}

Source: 2013/14 NGDs Audit Committee Report Disclosure

Table 3 shows the result of categories coded in the NGDs audit committee reports. Categories relating to the compliance with the Public Finance 
Management Act and the Treasury Regulation of the audit committee's charter, identity and qualifications of the NGDs audit committee members, attendance of meeting, state of internal audit in the NGDs, review of annual financial statements and management responses to issues raised by AGSA, effectiveness of internal audit directorates in addressing risks and monitoring of implementation of audit plans as well as engagements with AGSA to deal with unresolved matters were all highly reported in the audit committee reports of NGDs.

There were, however, areas where some NGDs audit committee reports lacked transparency and these areas included the indication in the audit committee report that internal controls were viewed as a cost effective way for providing assurance in the NGDs concerned, the role of audit committees in monitoring corrective actions, information reviews submitted by the management on pre-determined objectives, indications of whether the audit committee concerned was satisfied with the content and the quality of reports submitted monthly/quarterly by the management, reviews of compliance with legal and regulatory provisions, reviews of changes in accounting policies and practices, information reviews relating to the pre-determined objectives to be part of the annual report, information reviews relating to the significant adjustments made on annual financial statements following an audit engagement, the role of audit committees in reviewing the NGDs risk management strategy as well as monitoring of risk management activities including its implementation in the NGDs.

Table 4 below provides a detailed cluster analysis of information reported in the audit committee reports of NGDs.

Table 4 shows a detailed analysis of categories reported in the audit committee reports per cluster classification. The minus (-) sign in the table indicates that the NGD analysed in that particular cluster had not reported the information on the audit committee report reviewed. The analysis of Table 4 indicates that the finance and economic clusters perform better in terms of reporting the observed categories. On the contrary, the justice and social clusters appear to be prone to lesser reporting of the observed categories. 
Table 4: Cluster analyses of information reported in audit commmittee reports

\begin{tabular}{|c|c|c|c|c|c|c|c|c|c|c|}
\hline \multirow{2}{*}{ Category observed } & \multicolumn{2}{|c|}{$\begin{array}{l}\text { Central } \\
\text { cluster }\end{array}$} & \multicolumn{2}{|c|}{$\begin{array}{l}\text { Finance } \\
\text { cluster }\end{array}$} & \multicolumn{2}{|c|}{$\begin{array}{l}\text { Economic } \\
\text { cluster }\end{array}$} & \multicolumn{2}{|c|}{$\begin{array}{l}\text { Justice } \\
\text { cluster }\end{array}$} & \multicolumn{2}{|c|}{$\begin{array}{l}\text { Social } \\
\text { cluster }\end{array}$} \\
\hline & $\mathrm{Y}$ & $\mathrm{N}$ & Y & $\mathrm{N}$ & $\mathrm{Y}$ & $\mathrm{N}$ & $\mathrm{Y}$ & $\mathrm{N}$ & Y & $\mathrm{N}$ \\
\hline $\begin{array}{l}\text { Disclosure of identity and qualification of audit } \\
\text { members }\end{array}$ & 3 & -1 & 6 & 0 & 11 & -1 & 4 & -2 & 5 & -1 \\
\hline Disclosure of number of meetings by each member & 4 & 0 & 6 & 0 & 12 & 0 & 5 & -1 & 6 & 0 \\
\hline $\begin{array}{l}\text { Indication of whether there was compliance with } \\
\text { responsibilities arising from section } 38 \text { (1) (a) of the } \\
\text { Public Finance Management Act (PFMA) }\end{array}$ & 4 & 0 & 6 & 0 & 11 & -1 & 4 & -2 & 5 & -1 \\
\hline $\begin{array}{l}\text { Indication of whether there was compliance with } \\
\text { Treasury Regulation } 3.1\end{array}$ & 4 & 0 & 6 & 0 & 12 & 0 & 4 & -2 & 6 & 0 \\
\hline $\begin{array}{l}\text { Responsibility of adopting the formal terms of } \\
\text { reference as a charter }\end{array}$ & 3 & -1 & 6 & 0 & 12 & 0 & 5 & -1 & 6 & 0 \\
\hline $\begin{array}{l}\text { Responsibility of conducting the audit committee } \\
\text { affairs in compliance with the charter }\end{array}$ & 4 & 0 & 6 & 0 & 12 & 0 & 5 & -1 & 6 & 0 \\
\hline $\begin{array}{l}\text { Indication that internal controls are a cost effective } \\
\text { assurance for safeguarding of assets and effectively } \\
\text { liabilities and working capital }\end{array}$ & 0 & -4 & 4 & -2 & 3 & -9 & 0 & -6 & 2 & -4 \\
\hline $\begin{array}{l}\text { Reviewing the state of internal controls within the } \\
\text { NGD concerned indicating whether there were } \\
\text { instances of non-compliance and repeat findings }\end{array}$ & 4 & 0 & 6 & 0 & -10 & -2 & 6 & 0 & 5 & -1 \\
\hline $\begin{array}{l}\text { The role of audit committee in monitoring corrective } \\
\text { actions }\end{array}$ & 3 & -1 & 5 & -1 & 9 & -3 & 2 & -4 & 5 & -1 \\
\hline $\begin{array}{l}\text { Reviewing of reports relating to the information } \\
\text { submitted by management on the pre-determined } \\
\text { objectives (performance information) }\end{array}$ & 1 & 3 & 2 & -4 & 2 & 10 & 3 & -3 & 2 & -4 \\
\hline $\begin{array}{l}\text { Reviewed content and quality of monthly and } \\
\text { quarterly reports in the year under review }\end{array}$ & 2 & -2 & 3 & -3 & 8 & -4 & 5 & -1 & 2 & -4 \\
\hline Responsibility to review financial statements & 4 & 0 & 6 & 0 & 12 & 0 & 6 & 0 & 6 & 0 \\
\hline $\begin{array}{l}\text { Responsibility of reviewing ACSA's report and } \\
\text { management response to such a report }\end{array}$ & 3 & -1 & 4 & -2 & 9 & -3 & 5 & -1 & 5 & -1 \\
\hline $\begin{array}{l}\text { Responsibility of evaluating and reviewing changes to } \\
\text { accounting policies and practices }\end{array}$ & 2 & -2 & 4 & -2 & 8 & -4 & 3 & -3 & 4 & -2 \\
\hline $\begin{array}{l}\text { Responsibility of evaluating and reviewing } \\
\text { compliance with leg al and regulatory provisions }\end{array}$ & 2 & -2 & 4 & -2 & 6 & -6 & 4 & -2 & 4 & -2 \\
\hline $\begin{array}{l}\text { Evaluation and reviewing of the pre-determined } \\
\text { objective information to be part of the annual report }\end{array}$ & 3 & -1 & 3 & -3 & 4 & -8 & 3 & -3 & 3 & -3 \\
\hline $\begin{array}{l}\text { Evaluation and reviewing significant adjustments as a } \\
\text { result of audits (should there be any) }\end{array}$ & 3 & -1 & 3 & -3 & 8 & -4 & 3 & -3 & 5 & -1 \\
\hline $\begin{array}{l}\text { Reporting on the effectiveness of internal audit } \\
\text { function in addressing risks pertinent to the NGD } \\
\text { concerned }\end{array}$ & 3 & -1 & 4 & -2 & 11 & -1 & 4 & -2 & 6 & 0 \\
\hline $\begin{array}{l}\text { Monitoring implementation of audit plans approved } \\
\text { by the audit committee }\end{array}$ & 3 & -1 & 6 & 0 & 11 & -1 & 3 & -3 & 6 & 0 \\
\hline $\begin{array}{l}\text { Risk management reviews including reviewing of risk } \\
\text { management strategy }\end{array}$ & 1 & -3 & 5 & -1 & 7 & -5 & 2 & -4 & 5 & -1 \\
\hline $\begin{array}{l}\text { Monitoring of risk management activities including } \\
\text { the implementation plan in the NGD concerned }\end{array}$ & 1 & -3 & 6 & 0 & 7 & -5 & 2 & -4 & 5 & -1 \\
\hline $\begin{array}{l}\text { Engagement with Auditor General of SA so as to } \\
\text { ensure that there are no unresolved matters }\end{array}$ & 4 & 0 & 6 & 0 & 12 & 0 & 6 & 0 & 6 & 0 \\
\hline
\end{tabular}

Source: 2013/14 NGDs Audit Committee Report Disclosure

\section{Conclusion and recommendations}

The paper critically assesses audit committee reporting in South Africa's national government departments. During the review, it was established that, from the regulation perspective, there were limited guidelines relating to the extent and nature of information that should be reported on the audit 
committee reports, and consequently, it would be difficult to determine how audit committees performed their oversight role in the national government departments to combat undesirable effects as the mechanism which determine what should be reported on was not present. It was further established that it would be difficult to determine the nature of activities that audit committees were engaged in to improve the control environment in the national government departments in which they operate so as to communicate and build confidence with the stakeholders that something was being done to improve the control environment.

With the Auditor-General of South Africa (2013) raising concerns on continuing high levels of unauthorised, irregular as well as fruitless and wasteful expenditure in South Africa's public service, it is deemed important that audit committees in national government departments improve the mechanisms for eliminating or reducing the undesirable effects through a robust oversight, identification of risk areas requiring urgent attention and coordinating assurance on these and other areas under the ambit of the audit committees. All the areas of activity that the audit committee are engaged in should be communicated to the stakeholders through the audit committee reporting process.

The main contribution of the paper is a proposal for uniform benchmark features of audit committee reporting in the South Africa's national government departments. These categories were developed using an inductive or bottom up thematic analysis applied on the regulations and all national government departments' annual reports to determine the comprehensive themes and patterns of audit committee reporting across the departments. It is recommended that those audit committees in NGDs which do not currently report on these themes should expand their reporting to be comprehensive by including these themes.

Using the established benchmark features in the form of themes, audit committees reports were coded and analysed to determine the disclosure of information relating to these themes. Analysed results found that categories relating to compliance, identity and qualifications of the NGDs audit committee members, attendance of meeting, state of internal audit in the NGDs, review of annual financial statements and management responses to issues raised by AGSA, effectiveness of internal audit directorates in addressing risks and monitoring of implementation of audit plans as well as engagements with ACSA to deal with unresolved matters were all highly reported in the audit committee reports.

Majority of categories analysed, however, revealed that there were areas where some NGDs audit committee reports lacked transparency and these areas included the indication in the audit committee report that internal controls were viewed as a cost effective way for providing assurance in the NGDs concerned, the role of audit committees in monitoring corrective 
actions, information reviews submitted by the management on predetermined objectives, indications of whether the audit committee concerned were satisfied with the content and the quality of reports submitted monthly/quarterly by the management, reviews of compliance with legal and regulatory provisions, reviews of changes in accounting policies and practices, information reviews relating to the pre-determined objectives to be part of the annual report, information reviews relating to significant adjustments made on annual financial statements following an audit engagement, the role of audit committees in reviewing the NGDs risk management strategy as well as monitoring of risk management activities including its implementation in the NGDs.

In addition to the expansion of information reported in the audit committee reports as recommended above, audit committees in NGDs should also consider to voluntary disclose some additional information on their oversight activities in the NGD concerned. Disclosure of additional voluntary information would improve the usefulness of audit committee reports as users of this information would gain an understanding of yearly audit committee activities. Further, the nature of the oversight and engagements that the audit committee would have had with the management would come to the fore. The potential benefit for users of audit committee reports in NGDs is envisaged as unlocking exposure, flexibility and different dimensions in the nature of information reported by different NGDs. The potential benefits for audit committee members, for instance, would be an improvement in perception of their independence from the management (it is noted here that all audit committee reports analysed indicated that the members were independent).

Finally, there is a need to improve coherence in audit committee reporting. One of the areas observed was that the majority of audit committee reports indicated their satisfaction with the content and the quality of information provided by the monthly and quarterly management reporting. This implies that the audit committee was satisfied with the integrity of systems generating such information. This becomes contradictory as, on several occasions, it was noted that in the same audit committee reports, but in the "serious audit committee concern" category, the audit committees, on several occasions, raised lack of general controls in the information technology systems.

Tankiso Moloi, PhD is a professor in the Department of Financial Governance at the College of Accounting Sciences, University of South Africa. His research interest area is corporate governance. His qualifications include a PhD in Finance, a Master of Commerce in Accounting and a Master of Science in Financial Management. 


\section{References}

Agoglia, C. P., Doupnik, T. S., \& Tsakumis, G. T. (2011). Principle-Based versus Rules-Based Accounting Standards: The Influence of Standard Precision and Audit Committee Strength on Financial Reporting Decisions. The Accounting Review, 86(3), 747-767. DOI: $10.2308 /$ accr.00000045

Antaki, C., Billig, M., Edwards, D., \& Potter, J. (2002). Discourse Analysis Means Doing Analysis: A Critique of Six Analytic Shortcomings. DAOL Discourse Analysis Online [Electronic Version], 1(1).

Attride-Stirling, J. (2001). Thematic networks: an analytic tool for qualitative research. Qualitative Research, 1(3), 385-405. DOI: 10.1177/146879410100100307

Audit Committee Collaboration. (2012). Enhancing the audit committee report: a call to action. Retrieved 04.03.2015, from: http://www.auditcommitteecollaboration.org

Auditor-General South Africa (AGSA). (2013). Consolidated general report on the national and provincial audit outcomes. Pretoria: South Africa.

Beasley, M., Carcello, J. V., Hermanson, D. R., \& Neal, T. L. (2009). The Audit Committee Oversight Process. Contemporary Accounting Research, 26(1), 65-122. DOI: $10.1506 /$ car.26.1.3

Bhasin, M. L. (2012). Audit Committee Mechanism to Improve Corporate Governance: Evidence from a Developing Country. Morden Economy, (3), 856-872. DOI: $10.4236 / \mathrm{me} .2012 .37109$

Boyatzis, R. E. (1998). Transforming qualitative information: Thematic analysis and code development. Thousand Oaks, CA: Sage.

Braun, V., \& Clarke, V. (2006). Using thematic analysis in psychology. Qualitative Research in Psychology, 3(2), 77-101. DOI: 10.1191/1478088706qp063oa

Carcello, J. V., Hermanson, D. R., \& Neal, T. L. (2002). Disclosures in Audit Committee Charters and Reports. Accounting Horizons, 16(4), 291-304. DOI: $10.2308 /$ acch.2002.16.4.291

Daly, J., Kellehear, A., \& Gliksman, M. (1997). The public health researcher: A methodological approach. Melbourne, Australia: Oxford University Press.

Klein, A. (2002). Audit Committee, Board of Director Characteristics and Earnings Management. Journal of Accounting and Economics, 33(3), 375-400.

DOI: 10.1016/S0165-4101(02)00059-9

Marx, B. (2009). An Analysis of Audit Committee Responsibilities and Disclosure Practices at Large Listed Companies in South Africa. South African Journal of Accounting Research, 23(1), 31-44. DOI: 10.1080/10291954.2009.11435138

National Treasury. (2001). Treasury's Regulations. Pretoria: South Africa.

Rezaee, Z., Olibe, K. O., \& Minmier, G. (2003). Improving corporate governance: The role of audit committee disclosures. Managerial Auditing Journal, 18(6/7), 530-537. DOI: 10.1108/02686900310482669

Republic of South Africa. (1999). The Public Finance Management Act No. 1, 1999. Retrieved 04.02.2015 from: http://www.treasury.gov.za/legislation/PFMA/act. $\mathrm{pdF}$

The Financial Reporting Lab. (2013). Lab project report: Reporting of Audit Committees. UK: London.

Tuckett, A. G. (2005). Applying thematic analysis theory to practice: A researcher's experience. Contemporary Nurse, 19(1-2), 75-87.

DOI: $10.5172 /$ conu.19.1-2.75 
Van der Nest, D. P. (2005). Audit committees in Government Departments: An Internal Audit Perspective. Southern African Journal of Accountability and Auditing Research, 6(1), 75-84.

Van der Nest, D. P. (2008). The Perceived Effectiveness of Audit Committees in the South African Public Service. Meditari Accountancy Research, 16(2), 175-188. DOI: $10.1108 / 10222529200800019$

Van der Nest, D. P., Thornhill, C., \& de Jager, J. (2008). Audit committees and Accountability in the South African Public Sector. Journal of Public Administration, 43(4), 545-558. 
POVZETEK

\subsection{Originalni znanstveni članek}

\section{Kritična analiza revizijskih poročil v sektorjih državne uprave: primer Južne Afrike}

Ta članek kritično ocenjuje poročanje Revizijskih komisij v okviru Južnoafriških nacionalnih vladnih služb (NVS). Raziskava ima svoje omejitve, ocenjevala je, na primer, poročila revizijskih komisij v okviru nacionalnih vladnih služb. Pokrajinske vladne službe, institucije, ustanovljene na podlagi 9. poglavja Južnoafriške ustave (Poglavje 9, Institucije), občine in podjetja v državni lasti niso bile predmet ocenjevanja, zato to predstavlja priložnost za nadaljnjo raziskavo na tem področju. Poleg zgoraj omenjenih omejitev, štirih (4) letnih poročil NVS-jev ni bilo mogoče najti na njihovih uradnih spletnih straneh oziroma drugih potencialnih virov, nekaj nacionalnih vladnih služb pa se je združilo po splošnih volitvah maja 2014. Zato se ugotovitve, ki jih vsebuje ta članek, nanašajo na štiriintrideset (34) analiziranih NVS-jev.

Med pregledovanjem je bilo ugotovljeno, da so z vidika uredb smernice, ki se nanašajo na obseg in naravo informacij, o katerih bi morala poročati poročila revizijskih komisij, pomanjkljive, in kot posledica je bilo navedeno, da je bilo težko določiti, kako je revizijska komisija izvajala svojo nadzorno vlogo v nacionalnih vladnih službah v boju proti neželenimi vplivi, saj mehanizem, ki določa, o čem bi bilo treba poročati, ni bil predstavljen. Nadalje je bilo ugotovljeno, da je težko določiti naravo dejavnosti, ki so jih izvajale revizijske komisije, s pomočjo katerih lahko izboljšujejo okolje nadzora v NVS-jih, v katerih delujejo, da bi z zainteresiranimi stranmi gradile zaupanje in jim sporočile, da je nekaj bilo storjeno v zvezi z izboljšanjem okolja nadzora. Ko je Urad generalnega revizorja v Južnoafriški republiki (2013) izrazil zaskrbljenost nad nenehno visokimi nepooblaščenimi, neenakomernimi, neplodnimi in potratnimi izdatki v Južnoafriških javnih službah, se je zdelo pomembno, da revizijske komisije v okviru nacionalnih vladnih služb izboljšajo mehanizme, ki odpravljajo ali zmanjšujejo nezaželene vplive s pomočjo zanesljivega nadzora, prepoznavanjem področij tveganj, ki zahtevajo nujno pozornost in usklajevanje med temi in ostalimi področji, ki so pod revizijskimi komisijami. O teh in drugih področjih dejavnosti, s katerimi se ukvarjajo revizijske komisije, bi morale biti zainteresirane strani obveščene v okviru procesa poročanja revizijskih komisij.

Glavni prispevek tega članka predstavlja predlog o enotnih referenčnih mehanizmih poročanja revizijskih komisij v okviru Južnoafriških nacionalnih vladnih služb. Te kategorije so se razvile s pomočjo induktivne ali tematske analize po principu »od spodaj navzgor«, ki se uporablja na predpisih in vseh letnih poročilih NVS-jev, da so se lahko določile celovitih teme in vzorci poročanja revizijskih komisij po oddelkih. Priporočljivo je, da bi revizijske komisije $v$ NVS-jih, ki o teh temah trenutno ne poročajo, lahko dosegle celovitost poročanja z vključevanjem le-teh. Z uporabo uveljavljenih 
referenčnih mehanizmov v obliki tem so bila kodirana in analizirana poročila revizijskih komisij, da bi se lahko ugotovilo razkritje informacij v zvezi s temi temami. Analizirani rezultati so pokazali, da so bile vse kategorije, ki se nanašajo na skladnost, identiteto in usposobljenost članov revizijskih komisij, njihovo udeležbo na srečanjih, stanje notranje revizije v NVS-jih, pregled letnih računovodskih izkazov in odzivi uprave na vprašanja, ki jih je izpostavil Urad generalnega revizorja v Južnoafriški republiki, učinkovitost direktoratov za notranjo revizijo pri obravnavanju tveganj in spremljanje izvajanja revizijskih načrtov kot tudi sodelovanje z Uradom generalnega revizorja v Južnoafriški republiki pri reševanju nerešenih zadev, skrbno zajete v poročilih revizijskih komisij.

Kljub temu pa je večina analiziranih kategorij pokazala, da so bila poročila revizijskih komisiji na nekaterih področjih pomanjkljiva in na teh področjih je poročilo revizijskih komisij vsebovalo navedbo o notranji kontroli, ki je bila opredeljena kot stroškovno učinkovit način za pridobitev zagotovil v zadevnih NVS-jih, navedbo o vlogi revizijskih komisij pri spremljanju korektivnih ukrepov, navedbo o pregledanih informacijah o vnaprej določenih ciljih, ki so bili predloženi s strani uprave, navedbe o tem, ali je bila zadevna revizijska komisija zadovoljna z vsebino in kakovostjo poročil, ki jih je uprava predložila vsak mesec oz. vsako četrtletje, navedbe v zvezi s pregledom skladnosti z zakonskimi in regulatornimi določbami, navedbe o pregledanih spremembah v računovodskih usmeritvah in praksah, navedbe o pregledanih podatkih, ki se nanašajo na vnaprej določene cilje in ki so del letnega poročila, navedbe o pregledanih informacijah v zvezi s pomembnimi popravki v letnih računovodskih izkazih, narejenih po reviziji, navedbe o vlogi revizijskih komisij pri pregledu strategije obvladovanja tveganj v NVS-jih kot tudi navedbe o spremljanju dejavnosti v zvezi z obvladovanjem tveganj, vključno z njihovim izvajanjem v NVS-jih.

Poleg obsežnejših informacij, predstavljenih v poročilih revizijskih komisij, kot je bilo priporočeno zgoraj, bi morale revizijske komisije v NVS-jih razmisliti tudi o prostovoljnem razkrivanju nekaterih dodatnih informacij v zvezi z njihovimi nadzornimi dejavnostmi v zadevnih NVS-jih. Razkritje dodatnih prostovoljnih informacij bi pomagalo izboljšati uporabnost poročil revizijskih komisij, saj bi uporabniki teh informacij lahko bolje razumeli, s katerimi dejavnostmi so se med letom ukvarjale revizijske komisije. Nadalje bi to v ospredje izpostavilo naravo nadzora in sodelovanje, ki bi ga revizijska komisija morala imeti z upravo. Možna korist za uporabnike poročil revizijskih komisij v NVS-jih je predvidena v smislu proste poti pri izpostavljenosti, fleksibilnosti in v različnih vidikih narave informacij, o katerih poročajo različni NVS-ji. Možne koristi za člane revizijskih komisij pa bi bile, na primer, izboljšave v percepciji njihove neodvisnosti od uprave (tukaj je treba opozoriti, da so vsa analizirana poročila revizijskih komisij pokazala, da so bili člani neodvisni).

Nenazadnje bi bilo treba izboljšati skladnost poročanja revizijskih komisij. Na enem izmed področij je bilo ugotovljeno, da je večina poročil revizijskih komisij izrazila zadovoljstvo z vsebino in kakovostjo informacij, ki jih je uprava posredovala v svojih mesečnih oziroma četrtletnih poročilih. To pomeni, 


\section{Tankiso Moloi}

da so bile revizijske komisije zadovoljne z integriteto sistemov, ki so oblikovali te informacije. Nenazadnje je to protislovno, saj so revizijske komisije večkrat pokazale pomanjkljiv splošni nadzor sistemov informacijskih tehnologij, kar je bilo sicer zabeleženo v prav istih poročilih revizijskih komisij, vendar pod rubriko: resna zaskrbljenost revizijskih komisij. 